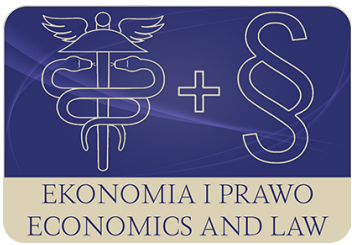

EKONOMIA I PRAWO. ECONOMICS AND LAW

Volume 20, Issue 4, December 2021

p-ISSN 1898-2255, e-ISSN 2392-1625

www.economicsandlaw.pl

ORIGINAL ARTICLE

received 10.05.2021; revised 01.12.2021; accepted 31.12.2021

Citation: Sulkowska, W. (2021). In search of opportunities for development of microinsurance by drawing on the experience of previous generations. Ekonomia i Prawo. Economics and Law, 20(4), 861-873. https://doi.org/10.12775/EiP.2021.051.

\title{
In search of opportunities for development of microinsurance by drawing on the experience of previous generations
}

\author{
WANDA SUŁKOWSKA \\ Cracow University of Economics, Institute of Finance, Department of Risk Management \\ and Insurance, ul. Rakowicka 27, 31-510 Kraków, Poland \\ $\square$ wanda.sulkowska@uek.krakow.pl \\ (iD) orcid.org/0000-0001-5947-0013
}

\begin{abstract}
Motivation: Notwithstanding the 30 years of the market economy, the Polish insurance market still reveals an exceptionally low level of penetration rates and insurance density. Attempts should be made to reduce the protection gap by introducing and popularising microinsurance products.
\end{abstract}

Aim: The research aims to establish whether there exists a need for microinsurance products in Poland and whether there are conditions for its development, which groups it should target and what methods and institutions can reduce the protection gap.

Results: Data analysis demonstrated that in Poland the lowest use of insurance coverage to manage risk occurs in the lowest income households, comprising groups of people with relatively low education: disability pensioners, farmers and workers. This results in lack of or limited access to insurance. Looking for a way to counteract this phenomenon, I suggest introducing and popularising microinsurance products targeting towards the above-mentioned groups. However, the use of remote microinsurance distribution channels may prove highly ineffective. Considering the above and the lack of trust in entities operating in the insurance market, it is recommended to create a legal environment enabling the inclusion of institutions and organisations acceptable to and enjoying the trust of these circles in processes involving marketing, distribution and, partially, the servicing of microinsurance. These players should consist of civic organisations, such as volunteer fire brigades, rural housewives' clubs, activist organisations from religious 
communities, as well as those set up for mutual protection, e.g., relief and loan funds and savings and loan funds. A separate group targeted by microinsurance should consist of people who are young, open to new trends and interested in obtaining insurance coverage for a limited time, e.g., for the short period when they use a means of personal transport or other rented equipment, for which coverage can be obtained and paid for quickly and without undue formalities.

Keywords: microinsurance; protection gap; financial exclusion; insurance market penetration rate; inclusive insurance JEL: J32; H55; G51; D15; G23

\section{Introduction}

The Polish insurance market is still a developing market and has a large untapped potential. Poland's position, despite its 30 years of growth, is very lowly. According to data by (Insurance Europe, 2021), in 2019 in Europe ${ }^{1}$, in terms of the penetration index ${ }^{2}$ and the insurance density index ${ }^{3}$ Poland ranked 18 and 20 respectively, in life insurance it ranked -22 and 23 , in health insurance -27 and 28 , in property and accident insurance -16 and 19. Both indexes are metrics of a relative nature, so they adequately reflect the level of development of the Polish insurance market relative to Europe and bear witness to a relatively high level of the protection gap. The problem of development barriers of the Polish insurance market has been the subject of numerous studies, conferences and works - both theoretical and focused on practical solutions. Despite many actions undertaken by insurance companies, the above situation does not change for the better.

In the last three years, as one of few of the EU's 28 member states, Poland twice experienced negative dynamics of gross paid and unpaid premiums on the previous year: in 2018 at $99.20 \%$, in 2020 at $99.24 \%$, and although in 2019 the dynamics of this premium in Poland were positive, the growth rate of a mere 101.82\% (Statistics Poland, 2019-2021) was very modest. This was despite the good financial standing of the vast majority of insurance companies, relatively good performance of the Polish economy and low unemployment rates. What is particularly disturbing is the systematic decline in gross paid and unpaid premiums in section I, but the situation in section II also gives reasons for concern, as the observed increase in paid and unpaid premiums largely results from an increase in the prices of insurance cover, especially in motor insurance, rather than the development of new market areas. To turn the situation around, it seems necessary to look for new, atypical products and methods of marketing, sales and support of insurance. Microinsurance is one of such, still untapped, areas in Poland. However, the bigger question is whether there

${ }^{1}$ Excluding the countries of the former Soviet Union.

2 Ratio of the value of gross paid and unpaid premiums to Gross Domestic Product GDP (in \%).

3 Value of gross paid and unpaid premiums per capita. 
is a market for this type of insurance in Poland and whether it is possible to sell this type of insurance effectively?

This research is generally aimed at determining whether there is a need for microinsurance in Poland and what are the conditions for its development. The paper concerns itself with the results of research aimed at identifying potential target groups for microinsurance in Poland, assessment of the possibility of using digital information technologies in their marketing, distribution and management, as well as with the necessary legal changes and identification of organisations that could be involved in the promotion, acquisition and servicing of microinsurance.

\section{Analysis of works of references on microinsurance}

\subsection{Review of current sources}

According to the International Association of Insurance Supervisors (IAIS, 2012, p. 11), microinsurance is defined as "insurance that is accessed by low-income populations, provided by a variety of different entities, but run-in accordance with generally accepted insurance practices (which include the ICPs ${ }^{4}$ )". The definition is clearly far from being comprehensive as it does not take into account the specificity of microinsurance. However, any attempts at creating a "proper" definition, which were being undertaken for years, were inherently doomed to failure, because for the purposes of legislation, it is necessary to take into account many elements, including mainly: (1) determination of the target group, (2) determination of product parameters, e.g. maximum insurance payout or the aggregate limit and/or the premium and benefit caps, (3) identification of eligible product providers, distribution channels and participating units, (4) methods of loss adjustment and payment of claims or benefits (Churchill \& Matul, 2012, pp. 8-10). The nature of factors, however, is variable and depends on the characteristics of the local community, the specificity of the market, including legal regulations and entities operating on the market, and even political conditions.

Based on the experience around the development of microinsurance so far, it is possible however to determine a general profile of its beneficiaries. The beneficiaries are people (households) who, for one reason or another, are unable or unwilling to use the traditional offer of insurance companies, mostly due to poverty resulting from low and often unstable income, lack of knowledge about insurance and inability to understand complex provisions of insurance contracts, la ck of trust in insurers and a negative perception of insurance per se (IAIS, 2015, pp. 7-8). Often these are households located in small, dispersed communities, far away from larger urban centres, hard to contact by means of traditional methods of information exchange between the insurer and the client

\footnotetext{
${ }^{4}$ Insurance Core Principles, see IAIS (2018b).
} 
(IAIS, 2018a). For these reasons, conventionally operating insurance companies have difficulties in reaching out to them with their offer by using traditional marketing methods and distribution channels. Considering the relatively high risk and service costs in relation to the expected profits, they do not even make such attempts, considering them to be unprofitable. And yet, given various entities' involvement and choice of non-standard activities, microinsurance has been growing intensively for over a dozen years, especially in developing countries, offering people - often financially excluded ones - in the event of illness, accident, loss of life or property damage, low level protection, which is difficult to overestimate in their social and occupational situation and ensuring their very survival in crisis situations and the possibility of further functioning (Haouassia et al., 2020; Merry, 2020; Qureshi \& Reinhard, 2019). For this reason, microinsurance is also called inclusive insurance and is one of the most important activities in the fight against financial exclusion ${ }^{5}$, Its development is often carried out on the initiative and with the support of government or local authorities, including in cooperation with companies guided by the principles of corporate social responsibility, as well as with non-governmental organisations.

The development of microinsurance is possible, however, when they meet specific conditions. Yet, it should be noted that even then, the functioning of microinsurance often requires additional legal regulation and financial support (Wiedmaier-Pfister \& Ncube, 2018). Relevant changes to the insurance law have already been made in dozens of countries, and this is further significantly facilitated by the application paper developed by (IAIS, 2012).

The current level of the global microinsurance market and its potential can be assessed on the basis of data from the report Microinsurance Network (Merry, 2020). Based on data provided by 194 insurers from 27 countries in Africa, Asia, Latin America and the Caribbean, it was established that as of 31 December 2019, 162-253 million people, i.e., 6-10\% of the low- and middle-income populations of these countries, used microinsurance. The total premiums collected in these countries totalled USD 1,060 million, and the combined potential of these microinsurance markets is estimated at USD 20,500 million. It is easy to calculate that the current collection of microfinance premiums accounts for a mere $5 \%$ of the market potential. In terms of the number of insureds and premiums collected, the structure of microinsurance indicates a predominance of personal insurance (96\% of the insureds) and $91.5 \%$ of the collected premiums. The last few years have seen significant changes in the structure of distribution channels. There is a clear trend to return to direct selling. Agents were engaged in $51 \%$ of microinsurance products sales and brokers in 39\%. Other channels include microfinance institutions, which accounted for $26 \%$ of sales, and internet aggregators ${ }^{6}$ for $12 \%$. Significantly, a sizeable role was played by as-

${ }_{5}$ Broad characterisation of financial exclusion in Europe and Poland presented in (Iwanicz-Drozdowska, 2008, pp. 3-11).

${ }^{6}$ Detailed characterisation of aggregators presented by Rychlik et al. (2019, pp. 1820). 
sociations, civic organisations, etc. which accounted for a total of $21 \%$ of the sales generated.

The importance of aggregators and public-private partnerships for the development of microinsurance markets was also emphasised in (Allianz, 2020, pp. 9-10).

Polish publications on microinsurance are rather thin on the ground. Chronologically, they include sources where: the need for cooperation of commercial and non-commercial insurers with the state under public-private partnership was indicated, especially in the field of cover related to natural disasters (Kurek, 2009a, pp. 165-175); it was shown that insurance companies operating either as joint-stock companies or mutual insurance companies can successfully engage in microinsurance activities (Kurek, 2009b); attention was drawn to the possibility of including microinsurance in the social security system (Kawiński, 2010); groups of potential recipients and determinants of the demand for microinsurance were characterised in general terms and potential target groups in Poland were indicated according to the poverty risk criterion (Stańko, 2010, pp. 105-119); microinsurance was included among the main microfinance products (Solarz, 2011); with a potential to be used in medium and highly developed countries, mainly to ensure insurance inclusion of the poorest (Bednarczyk, 2016); including not only households but also micro, small and medium-sized businesses, e.g. from the transport industry (Zieniewicz, 2014, pp. 359-366), and the role of microinsurance as a factor of inclusion counteracting social exclusion was emphasised (Bera, 2018, pp. 65-71). This perception of microinsurance was developed in the first decade of the 21st century and was also strongly confirmed in (Swiss Re Institute, 2010).

However, is and should the current target group of microinsurance, i.e., the poorest, be the main determinant of microinsurance? In my opinion, that the specific features of these products, their inclusive nature and innovation should be considered, and that this will allow microinsurance to be considered as a modern product. From this point of view, today we can talk about a completely new, very rapidly developing segment of the microinsurance market, with an offer targeting customers who are young, often already wealthy, but busy, too focused on other matters to analyse a complex traditional insurance product. The most recent examples include third party liability insurance, accident insurance and personal transport assistance. Also in this case, their inclusive and educational function is clearly manifest. Thanks to them, insurance companies acquire new clients, although they are definitely different in terms of their socio-economic situation. As in the case of microinsurance addressed to financially excluded groups, the use of digital technologies within the framework of InsurTech, blockchain technology (Meeusen, 2016) and smart contracts (Stolarski \& Gałczyk, 2018) is a distinct feature of the above-mentioned types of insurance. 


\subsection{References to the past}

The problem of protection against natural disasters sustained by low-income people has been a serious challenge for centuries, also in terms of such protection in Polish territories. The challenge was addressed by means of numerous initiatives in the form of risk pooling communities within professional groups or local communities. Thus, the late Middle Ages saw a spontaneous creation of Brotherhood Funds and Brother's Union by miners and steelworkers, initially established in present day Upper Silesia (Popiołek, 1946), funds for miners established by Olkusz miners in 1671 (Woźniczka, 1960), or the so-called Levee Associations operating in the 17th and 18th centuries in Żuławy, Fire Societies and Orders for Cities and Villages (Krzeczkowski, 1931, p. 15 et seq.), subsequently replaced by fire societies (Eazowski, 1934). In the 19th century, TUW Florianka ran an insurance business in Krakow. Apart from major contributions to the development of property insurance, especially fire insurance, the TUW became famous for the so-called folk insurance, which quickly became quite popular. These simple, relatively cheap life assurance products, sold without visual inspection or medical check-up, were suited to the modest means and expectations of impecunious customers: small farmers, craftsmen and merchants (Banasiński, 1993).

\section{Methods}

In the research process, use was made of widely used research methods and techniques: research, largely using digitised library resources and internet sources, critical analysis of available publications, analysis of existing data, i.e., secondary research using the desk research method. The research consisted of the exploration of data published by the Central Statistical Office (Statistics Poland). Financial wealth was assumed as the basic determinant of the demand for household insurance, and the average annual equivalised disposable income per person was used as a metric, hereinafter referred to in short as "disposable income". Based on this criteria, three groups of potential micro-insurance recipients were selected, and then the level of further determinants of the demand for these types of insurance were examined, i.e. education, the insurance gap as well as the availability and use of the Internet when utilizing financial services. Based on the results of the analysis, the characteristics of target groups in Poland for micro-insurance were determined. 


\section{Determination of target groups for microinsurance products}

\subsection{Groups with severely constrained financial resources}

By their nature, micro-insurance is targeting the lowest income groups. In order to identify these groups, the data for the period from January to December 2018 (Statistics Poland, 2021) was used. The study covers four socio-economic groups with the lowest equivalised disposable income: disability pensioners, farmers, pensioners and employees. The group of disability pensioners receives definitely the lowest income, almost twice as low as pensioners ranked third. On the other hand, farmers stand almost halfway on the income scale between the two above groups. Employees' households boast the largest disposable income of the study groups - more than 2.5 times higher than pensioners', but the income differentiation in two groups of employees should be considered.

The analysis shows that when the income criterion is used, the target group for microinsurance should include pensioners, farmers and workers from the eastern macroregion residing in rural areas and small towns. The subsequent analysis is aimed at refining the knowledge about these groups of households. This recommendation ignores pensioners due to their age and unique needs for insurance protection and the fact that this group has already attracted the attention of some insurance companies which have developed dedicated products. At the same time, taking into account that the activities in the field of microinsurance in Poland for which this publication is supposed to win an audience, would be a pilot project, only the eastern macroregion was selected, although the disposable income in the northern, north-western and central macroregions is also relatively low.

Undoubtedly, one of the most important factors affecting the demand for insurance is the education of potential insureds. Its importance is underscored by the impact of education on earnings and on insurance awareness. The first interdependence is confirmed by data from (Statistics Poland, 2020b). The highest level of disposable income, about 30\% higher than the average income, is found in households of people with higher education. On the other hand, the income in the next three groups is lower than the average income and as the level of education decreases, it drops by approximately $15 \%$. Bearing this in mind, it is necessary to consider the level of education in the previously selected groups of households. On the basis of (Statistics Poland, 2020b), it can be demonstrated that in the study groups of households, the majority of people boast less than secondary education, at $60.4 \%$ for workers, $62.9 \%$ for farmers and $68.9 \%$ for disability pensioners. 


\subsection{Groups using least risk management insurance}

In order to target the right microinsurance towards the right audience, it is necessary to consider the areas with the largest protection gap, distinguishing between groups of people and types of insurance. Unfortunately, publicly available data on this subject is very sparse and fragmentary. According to (Statistics Poland, 2020b), the average expenditure of households on total non-life insurance in Poland is exceptionally low (PLN 19.88/month), and the corresponding expenditure in the three study groups of households is even a quarter less. If one bears in mind that the majority of these expenses is related to compulsory insurance, then voluntary insurance spending turns out to be negligibly small.

\subsection{Availability and use of the internet by potential beneficiaries of microinsurance}

The rapid development of microinsurance in other countries, especially in Africa, has been largely enhanced by the use of digital communication technologies and cooperation with mobile network operators and internet aggregators. Can this experience be utilised in Poland? The answer depends on the availability and use of the internet by recipients of microinsurance. According to (Statistics Poland, 2020c) data for 2020, Internet access in towns of up to 100000 inhabitants and in the countryside was reported by $89.5 \%$ of Polish households, but only by $81.2 \%$. of rural households. The lowest availability and use of the Internet was ascertained for lowest income households, where it stood at $84.7 \%$ and $82.3 \%$, respectively. Internet access was the lowest among pensioners and disability pensioners, at $64.3 \%$ and farmers at $74.4 \%$ respectively. In these two groups, gender was a minor differentiating factor, although in the worker group it favoured men by 8 percentage points. Taking only broadband lines into account - in 2020, 68.6\% of households in towns and cities of up to 100,000 inhabitants had a fixed line, compared to $60.1 \%$ in the countryside, and $67.2 \%$ and $68.3 \%$ respectively had a mobile connection. These ratios for the lowest-income households stood at $60.3 \%$ and $60.9 \%$, and in the 2000-2,666.67 PLN income bracket, at $68.4 \%$ and $67.2 \%$ respectively. On the most important issue from the point of view of microinsurance, i.e., the use of online financial services, the lowest ratio was ascertained for pensioners' and disability pensioners' households at $25.9 \%$ and at $30.3 \%$ for farmers' households. In the group of households with an average monthly net income of up to PLN 2,666.67, online banking was available to $38.8-48.5 \%$ of households, and considering the place of residence, in towns and cities of up to 100,000 inhabitants financial services were accessed online by $51.8 \%$ of the households, and in the countryside by $39.3 \%$ of the same. 


\section{Conclusions}

Based on the above analyses, the target group for inclusive insurance in Poland consists of three subgroups: workers, farmers and disability pensioners, and the economic situation should be used as the criterion by which households should be allocated to these groups.

Out of the many possible criteria, I suggest adopting the poverty threshold defined by the Institute of Labour and Social Affairs. This threshold, commonly referred to as the social minimum, demarcates the zone of social exclusion and constitutes the cut-off point below which deprivation of integration needs occurs. It varies, depending on the type of household (8 types). For example, (Statistics Poland, 2020a) reported that in 2019 the threshold of the poverty sphere for one-person workers' households stood at PLN 1218, for four-person households ( 2 adults and 2 children below 14 years of age) at PLN 3,287; at PLN 1195 for one-person farmer's, pensioner's and unearned income sources' households and at PLN 3,226 for their four-person households. In 2019, the sphere of social exclusion affected a total of $39.4 \%$ of people in households.

The analysis shows that the largest number of households meeting the above criterion is situated in the villages and small towns of the eastern macroregion. In all the study groups, people with basic vocational education constitute the single biggest sample, accounting for at least $35 \%$ of households in the social exclusion zone. In the case of households of workers and farmers, the second place is occupied by people with secondary vocational and comprehensive education at $30.8 \%$ and $28.3 \%$ respectively, and in the case of disability pensioners' households by people with primary education status and without education, at $28.9 \%$. Such a significant advantage of people with relatively low education causes that the perception of risk and insurance awareness in the above-mentioned groups are at a low level. This was indirectly confirmed by studies into the degree of use of insurance by households from these three groups. The average household expenditure on total non-life insurance is exceptionally low in Poland, and such expenditure in the three study groups of households is even lower by approximately a quarter. Barring compulsory insurance, the remaining amounts turn out to be negligible, which proves that insurance coverage for potential damage is far from what is it really needs to be. This confirms the assumption that income and education are strong drivers of insurance demand.

One of the most important factors underlying the choice of microinsurance distribution channels is the knowledge about the possibilities of using digital information technologies, in particular fixed and mobile Internet access. In the study groups of households in rural areas and smaller towns, and people with low and secondary education, in general, both access to and use of the Internet in 2020 were reasonably good, standing at approx. 90\% and $80 \%$, respectively, but a breakdown by professional status paints a disconcerting picture, showing that the internet was used by only $74.4 \%$ of farmers' and $64.3 \%$ of disability pensioners' households, while a fast connection was generally availa- 
ble to approx. $60-68 \%$ of these households. Significantly, however, the rural population had more mobile lines than fixed lines. The data on the use of online financial services boded worse - and markedly so - for the possibility of the Internet being used in the distribution and support of microinsurance in Poland. In 2020, online banking was used by merely $25.9 \%$ of disability pensioners and pensioners and $30.3 \%$ of farmers, although the data for the two lowest income groups are higher by approximately 12 percentage points.

The above constraints indicate the need for the use of direct marketing and given that it is absolutely essential to educate customers about and change their attitudes towards insurance and insurers, also the need to use reliable and trusted institutions and social organisations to ensure the outcome. The experience of numerous countries indicates that this type of entities can also be highly effective in participating in the sale of microinsurance and can even be helpful in loss adjustment. In Poland use can be made of existing civic organisations, such as volunteer fire brigades (OSP) or rural housewives' clubs (KGW) which boast over 100 years of tradition, and even older organisations of activists in religious communities, as well as mutual aid societies, e.g., relief and loan funds and savings and loan funds. However, such a broad scope of inclusion of entities from outside the insurance market requires significant legislative change. It is a difficult undertaking but using the experience of various countries and the IAIS application document, it is fully practicable. It is also necessary to try to create new institutions through which it will be possible to reach selected groups of recipients and thus gradually make progress in this field.

Experience shows that the microinsurance offer should be targeted separately towards separate groups of recipients: (1) poor people, whom their low level of income excludes from the group of recipients/users of standard products; (2) people viewing new offers with distrust and great caution, but willingly listening to the opinions of individuals and institutions who have long been trusted by them, e.g. volunteer fire brigades, country housewives' clubs or activists in religious communities; (3) people with conservative attitudes, willing to accept traditional forms of mutual protection (relief and loan funds and savings and loan funds, or other forms such as small mutual insurance companies); (4) people open to new trends.

Still, however, the basic role, and even the mission, of microinsurance is related to its inclusive function for financially excluded social groups. In the period of the pandemic Ongoing since March 2020, it has been gaining even greater importance in the light of the deepening financial stratification of the Polish society, reflected in incomes shaped in the form of the letter $\mathrm{K}$ (the poor - get poorer; the rich - get rich faster and faster) and the actualization of many types of risks - both those previously covered by traditional protection, and those that are completely new. This may cause the protection gap to grow rapidly. Therefore, intensification of efforts aimed at reducing insurance exclusion in Poland with the use of microinsurance is fully justified. 


\section{References}

Allianz. (2020). Emerging consumer 2019 full year report. Retrieved 11.02.2021 from https://www.allianz.com/content/dam/onemarketing/azcom/Allianz_com/sustainability/documents/Allianz-Emerging-Consumers-Report-FY2019.pdf.

Banasiński, A. (1993). Ubezpieczenia gospodarcze. Poltext.

Bednarczyk, T.H. (2016). Mikroubezpieczenia: innowacja produktowa czy powrót do korzeni. Prace Naukowe Uniwersytetu Ekonomicznego we Wroctawiu, 415, 23-32. https://doi.org/10.15611/pn.2016.415.02.

Bera, A. (2018). Microinsurance in limiting insurance exclusion. European Journal of Service Management, 28/2(4), 65-71. https://doi.org/10.18276/ ejsm.2018.28/2-07.

Churchill, C., \& McCord, M.J. (2012). Current trends in microinsurance. In C. Churchill, \& M. Matul (Eds.), Protecting the poor: a microinsurance compendium, 2, 8-39. International Labour Office.

Haouassia, S., Leibforth, B., Copas, T., \& Porter, H. (2020). Research report: investigating the social component of insurers' sustainability practices. Retrieved 11.02.2021 from https://business.illinoisstate.edu/downloads/katie/microinsurance/Investigating\%20the\%20Social\%20Component\%20of\%20Insurers\%20Sustainability\%20Practices.pdf.

IAIS. (2012). Application paper on regulation and supervision supporting inclusive insurance markets. Retrieved 12.02.2021 from https://www.iaisweb.org/ page/supervisory-material/application-papers//file/34110/application-paper-on-regulation-and-supervision-supporting-inclusive-insurance-markets.

IAIS. (2015). Issues paper on conduct of business in inclusive insurance. Retrieved 22.02.2021 from https://www.iaisweb.org/page/consultations/ closed-consultations/2015/issues-on-conduct-of-business-in-inclusive-insurance.

IAIS. (2018a). Application paper on the use of digital technology in inclusive insurance. Retrieved 26.02.2021 from https://www.iaisweb.org/page/ supervisory-material/application-papers//file/34110/application-paper-on-regulation-and-supervision-supporting-inclusive-insurance-markets.

IAIS. (2018b). Issues paper on index based insurances, particularly in inclusive insurance markets. Retrieved 26.02.2021 from https://www.iaisweb.org/ page/supervisory-material/issues-papers//file/75169/issues-paper-on-index-based-insurances-particularly-in-inclusive-insurance-markets.

Insurance Europe. (2021). European insurance in figures 2019 data. Retrieved 24.02.2021 from https://www.insuranceeurope.eu/publications/689/european-insurance-in-figures-2019-data/EIF\%202021.pdf.

Iwanicz-Drozdowska, M. (2008). Wykluczenie finansowe: poważny problem społeczny. Central European Management Journal, 16(1), 2-11. 
Kawiński, M. (2010). Instytucja mikroubezpieczeń. In T. Szumlicz (Ed.), Społeczne aspekty rozwoju rynku ubezpieczeniowego (pp. 311-324). Szkoła Główna Handlowa w Warszawie.

Krzeczkowski, K. (1931). Rozwój ubezpieczeń publicznych w Polsce (volume 1). Powszechny Zakład Ubezpieczeń Społęcznych.

Kurek, R. (2009a). Mikroubezpieczenia na świecie: działania komercyjne i niekomercyjne inicjatywy wspierające. Prace Naukowe Uniwersytetu Ekonomicznego we Wroctawiu: Nauki o Finansach, 1(61), 165-175.

Kurek, R. (2009b). Ubezpieczenia wzajemne jako forma sprzedaży mikroubezpieczeń. In P. Karpuś, \& J. Węcławski (Eds.), Rynek finansowy w erze zawirowań (pp. 539-546). Uniwersytet Marii Curie-Skłodowskiej w Lublinie.

Łazowski, J. (1934). Wstęp do nauki o ubezpieczeniach. Powszechny Zakład Ubezpieczeń Wzajemnych.

Meeusen, P. (2016). Blockchain insurance industry initiative. Retrieved 04.02.2021 from https://finance20.ch/web/wp-content/uploads/2016/11/04_ Meeusen_InsurTechl6.pdf.

Merry, A. (2020). The landscape of microinsurance 2020. Retrieved 21.01.2021 from https://microinsurancenetwork.org/sites/default/files/MiN-Landscape-2020-ENGLISH_vf_0.pdf.

Popiołek, F. (1946). Opieka społeczna w przemyśle hutniczo-górniczym na ziemiach polskich. Śląska Gazeta Lekarska, 2(2), 33-38.

Qureshi, Z. \& Reinhard, D. (Eds.). (2019). Report: 15th International Conference on Inclusive Insurance: copying with climate risk. Retrieved 04.02.2021 from https://www.munichre-foundation.org/content/dam/munichre/foundation/publications/2020_ICII_2019_final.pdf/_jcr_content/renditions/ original.media_file.download_attachment.file/2020_ICII_2019_final.pdf.

Rychlik, D., Domański, R., Obuchowicz, M. \& Dudycz, K. (2019). Internetowi agregatorzy. Miesięcznik Ubezpieczeniowy, 18(11), 18-20.

Solarz, M. (2011). Wybrane sposoby ograniczania zjawiska wykluczenia ubezpieczeniowego. Annales Universitatis Mariae Curie-Sklodowska: Sectio H, Oeconomia. 45(2), 363-371.

Stańko, D. (2010). Mikroubezpieczenia jako metoda ochrony przed ryzykiem ubóstwa. Czynniki kształtujące popyt i rozwój produktowy. Wiadomości Ubezpieczeniowe, 3, 105-119.

Statistics Poland. (2019-2021). Financial results of insurance companies in 2018-2020. Retrieved 11.02.2021 from https://stat.gov.pl/en/topics/ economic-activities-finances/financial-results/financial-results-of-insurance-companies-in-2020,14,37.html.

Statistics Poland. (2020a). Economic poverty rates in Poland in 2019. Retrieved 11.02.2021 from https://stat.gov.pl/en/topics/living-conditions/social-assistance/economic-poverty-rates-in-poland-in-2019,4,7.html.

Statistics Poland. (2020b). Household budget survey in 2019. Retrieved 11.02.2021 from https://stat.gov.pl/en/topics/living-conditions/living-conditions/ household-budget-survey-in-2019,2,14.html. 
Statistics Poland. (2020c). Wykorzystanie technologii informacyjno-komunikacyjnych w jednostkach administracji publicznej, przedsiębiorstwach i gospodarstwach domowych w 2020 roku. Retrieved 11.02.2021 from https://stat.gov.pl/ obszary-tematyczne/nauka-i-technika-spoleczenstwo-informacyjne/ spoleczenstwo-informacyjne/wykorzystanie-technologii-informacyjno-komunikacyjnych-w-jednostkach-administracji-publicznej-przedsiebiorstwach-i-gospodarstwach-domowych-w-2020-roku,3,19.html.

Statistics Poland. (2021). Incomes and living conditions of the population in Poland: report from the EU-SILC survey of 2019. Retrieved 11.02.2021 from https:// stat.gov.pl/en/topics/living-conditions/living-conditions/incomes-andliving-conditions-of-the-population-in-poland-report-from-the-eu-silcsurvey-of-2019,1,12.html.

Stolarski, P., \& Gałczyk, J. (2018). Wykorzystanie technologii inteligentnych kontraktów jako platformy dla mikroubezpieczeń. Prace Naukowe Uniwersytetu Ekonomicznego we Wroctawiu, 541. 257-267. https://doi.org/10.15611/ pn.2018.541.20.

Swiss Re Institute. (2010). Microinsurance: risk protection for 4 billion people. Retrieved 11.02.2021 from https://www.swissre.com/institute/research/sigma-research/sigma-2010-06.html.

Wiedmaier-Pfister, M., \& Ncube, S. (2018). Regulating mobile insurance: insurance business via mobile phones: regulatory challenges and emerging approaches. Retrieved 16.02.2021 from https://www.a2ii.org/es/knowledge-center/ regulating-mobile-insurance-insurance-business-via-mobile-phones-regulatory-challenges-and-emerging-approaches.

Woźniczka, F. (1960). W dziesiątą rocznicę ustanowienia rent z Karty Górnika. Praca i Zabezpieczenie Spoteczne, 12, 1-10.

Zieniewicz, M. (2014). Mikroubezpieczenia szansą dla mikro- i małych przedsiębiorstw w Polsce: przykład branży transportowej. Prace Naukowe Uniwersytetu Ekonomicznego we Wroctawiu, 342, 359-366.

\section{Acknowledgements}

Author contributions: author has given an approval to the final version of the article.

Funding: this research was fully funded by the Cracow University of Economics.

Note: the results of this study were presented at the 8th International Conference Sustainable Finance \& Accounting: Economy, Ethics, Environment (April 19-21, 2021, Torun, Poland). 
